\title{
PECULIARITIES OF CRIMINOLOGICAL CHARACTERISTICS OF CRIMINALS IN THE BORDER BLACK SEA REGIONS OF MAINLAND UKRAINE
}

\section{Konopelskyi V. Ya.}

\section{INTRODUCTION}

Today Ukrainian society is undergoing fundamental reforms aimed at European integration and decentralization. Brand-new standards of law enforcement activity are being introduced. Thus, crime combating is being transferred to the regional level. In this context, $21^{\text {st }}$ century brought new geopolitical and criminological challenges, such as: infringement of the territorial integrity of the country; offence against the inviolability of its state borders; rise in the common crime rate, spread of terrorism, murders, smuggling, arms trafficking, drugs, human trafficking, etc. The quantitative and qualitative indicators of the state of regional crime, in particular in the border regions of Ukraine, have changed drastically. Today's criminals cover more than just one particular area or the territory of the district, city, region, and even the country. Today's regional crime in the border regions has become more mobile and flexible, and the criminals become more skilled and active in introducing new forms, types and methods of criminal activity. Thanks to the information available, criminality becomes more hardcore. This being so, the geopolitical challenges, as well as the poor regional and national system and the strategy for crime prevention, turn the southern border regions of Ukraine into a zone suitable for the unlawful activity of underworld figures.

Thus, according to the official statistics of the Ministry of Internal Affairs and the General Prosecutor's Office of Ukraine, there is a significant degradation of the quantitative and qualitative indicators of crime in the border Black Sea regions. For instance, for the period from 2012 to 2017, the average crime rate in Ukraine increased by $+4 \%$ (from 504.027 to 523.911), in Odesa region it increased by $+33 \%$ (from 24474 to 32576), in Mykolaiv region it increased by $+63 \%$ (from 10310 to 16798) and in Kherson region it increased by $+46 \%$ (from 11452 to 16760). The intensity of crime per 100 thousand people also shows 
downward dynamics. In 2017, it is one third higher if compared with 2012: in Mykolaiv region from 879 to 1460 (+66\%); in Odesa region from 1027 to $1365(+33 \%)$; in Kherson region from 1063 to 1587 $(+49 \%)$, which far outweighs the average Ukrainian indicators showing the crime intensity raised from 1110 to $1230(+11 \%)$.

It is necessary to note the gravity of crimes in the southern border regions of Ukraine. For instance, just in 2017, Odessa region had 54\% (17697) of serious and particularly serious crimes committed, in Mykolaiv region it was $41 \%$ (6859), in Kherson region it was $41 \%$ (6922), while the Ukraine-wide indicators were $40 \%$ (214660) of all crimes. As it is, Ukrainian regions, in particular, border ones, faced troubled social and criminological realities, which, in their turn, require brand-new crime analysis and counteraction approaches. Thus, the phenomenon of crime should be understood as a regional and crossborder issue. It is crucial to find out new ways of improvement of the effectiveness of law enforcement bodies in the border Black Sea regions of mainland Ukraine.

\section{Criminological Characteristics of the Criminal}

Crime is one of the extreme forms of evil. There is always a specific individual, a member of society standing for the crime. Such an individual is a kind of reflection of the defects and flaws of society. That is why the issue of personality of the criminal is one of the leading and most difficult issues in criminal science. Scientists hold violent discussions of the personality of the criminal since it is the key and most important link in the entire mechanism of criminal behavior. The peculiarities of the personality of the criminal, which causes such behavior, should be the object the preventive measures are focused on.

According to V.I. Shakun, the introduction into the scientific terminology of the criminological category of a 'personality of the criminal', its theoretical study, understanding, and practical application are crucial for preventive measures. First and foremost, this category emphasizes the fact that the criminal is still an individual, even if antisocial one. Thus, the relevant law-enforcement bodies, investigative bodies, and the penitentiary administration should have an appropriate level of attitude, free from dishonor. Consequently, the study of the personality of the criminal should not be limited to criminal and juridic 
characteristics. The data on social and demographic status are very important. ${ }^{1}$

According to the results of A.A. Kovalkin's research, the summarized criminological characteristic of certain types and categories of criminals makes it possible to distinguish their specific crime-causing features and traits, determine criminogenic population groups, predict criminal behavior of some individuals, and work out appropriate preventive measures to be applied to them. ${ }^{2}$ In turn, one of the crucial aspects of the study of personality of the criminal is the study of criminologically important peculiarities that are present in all criminals. According to O.H. Kulik, this study is necessary to identify the main principles of determination of crime and work out preventive measures to be applied. ${ }^{3}$ Modern criminological approaches ${ }^{4}$, tend to understand the criminal as a person with socially significant characteristics, signs, connections and relationships peculiar to the criminal, being combined with other (non-personal) conditions and circumstances that cause criminal behavior.

Today the advanced knowledge of the criminological peculiarities of quantitative and qualitative changes, social and psychological changes, as well as the level of criminal manifestations in the specific territory makes it possible to get a better theoretical understanding of the nature of anti-social behavior. In terms of practice, law enforcement bodies have the opportunity to get a broader picture of the geography of criminals, their quantitative and qualitative characteristics and work out the crime prevention measures that would respond to the criminal activity of the population on a specific territory. For instance, there is always a specific person standing for each crime and a certain number of persons standing for the number of crimes.

\footnotetext{
${ }^{1}$ Шакун В. І. Урбанізація і злочинність : монографія. Київ: УАВС, 1996. 256 с.

2 Ковалкин А. А. Личность преступника и некоторые способы её криминологического анализа. Проблемы изучения личности правонарушителя: сб. научн. тр. Москва: Изд-во ВНИИ МВД СССР, 1984. 158 с.

3 Кулик О. Г. Кримінологічна характеристика осіб, які вчинили злочини в Україні: сучасні тенденції. Юрид. Україна. Сер.: Кримінально-правові науки. 2013. № 7. C. 98-102.

4 Чекмарьова I. М. Особливості кримінологічних ознак особи злочинця для запобігання злочинності. Development of Legal Regulation in East Europe: Experience of Poland and Ukraine (Sandomierz, Poland, 27-28.01.2017). Sandomierz, Poland, 2017. C. $178-181$.
} 
Modern criminological studies name from 4 to 7 main peculiarities and from 30 to 40 constituent elements of these peculiarities, which form the theoretical fundamental of the criminological characteristics of the personality of the criminal. ${ }^{5}$ They include social and demographic (gender, age, education, marital status, occupation, place of residence, etc.); social and role (immediate environment, everyday relations, family relations, etc.); criminal (data on the type of crime, criminal behavior drive, individual or group nature, the type of backslide, etc.); moral and psychological (mindset, spiritual dimension, views, setting, beliefs, values-based orientations, etc.), etc. ${ }^{6}$ Depending on the purpose, objectives and level of the study, not all of the given elements, compounds and traits of the criminal are comprehensively analyzed within the thematic criminological study. Due to the complexity of the issues of the study of regional crime, even doctoral dissertations highlight the results of the analysis of dynamics, structural distribution and peculiarities of the territorial spread of criminals. Typically, criminological data characterizing the personality of the criminal are presented by the results of scientific studies specifying the results that describe the peculiarities of the structure of the identified criminals. Scientists also analyze the distribution of crimes in terms of geographic spread and dynamics, study the main social and demographic, criminal and criminological peculiarities of the personality of the criminal. ${ }^{7}$

In a point of fact, it is quite hard to resolve the abovementioned issues within any regional criminological analysis since we are talking about the characteristic within a great number of heterogeneous territorial and spatial as well as social and demographic entities. The main issues faced by a scientist: first, it is difficult to obtain information from official sources; second, there is the lack of relevant information within the territory; third, there is the lack of schemes and methods for collecting and processing such information in the framework of comparative analysis; fourth, the scope of scientific study is limited.

${ }^{5}$ Кримінологія: Загальна частина : альбом схем / авт. -упоряд.: Денисов С. Ф., Денисова Т. А., Кулик С. Г., Шеремет О. С.. Чернігів: Десна, 2015. 658 с.

6 Джужа О. М, Кондратьєв Я. Ю., Кулик О. Г. та ін. Кримінологія : підручник. Київ: Юрінком Інтер, 2002. 416 с.

7 Кулик О. Г., Наумова I. В., Бова А. А. Злочинність в Україні: фактори, тенденції, протидія (2002-2014pр.) : монографія. Київ: ДНДІ МВС України, 2015. 364 c. 
Within our study, the criminological characteristic of personality of the offender is an analysis of the system of traits altogether giving an idea of the territorial distribution of criminals; data on the levels of criminal activity on the specific territories; dynamic changes and trends of such activity in the regions being studied; social and legal, criminological and other peculiarities of population groups engaged in a crime in a specific region, which are important sources to organize crime prevention the southern border regions of Ukraine.

According to official statistics, eastern regions of Ukraine tend to have the greatest number of crimes and criminals in recent years. Thus, in 2015, out of 565.182 crimes recorded and 18.809 suspects, 50.146 crimes were recorded in Dnipropetrovsk region, where only $17.669(35 \%)$ persons were served a notification of suspicion; 41.804 crimes were recorded in Zaporizhzhia region, and 139.72 (33\%) persons were served a notification of suspicion; in Kharkiv region 40.949 crimes were recorded, while $127.81(31 \%)$ persons were served a notification of suspicion. Thus, of all crimes committed in the country, almost a quarter $(24 \%)$ is recorded in 3 eastern regions of Ukraine. ${ }^{8,9}$

As for the southern border regions of Ukraine, practically every tenth crime is committed in Odesa, Mykolaiv or Kherson region. In recent years, these regions tend to have a significant rise in crime rate and a decreased level of crimes disclosure. For instance, in 2015, in Odesa region there were 29364 crimes recorded and only 9212 (31\%) persons were served a notification of suspicion; in Kherson region there were 16071 crimes recorded and $8036(50 \%)$ persons were served a notification of suspicion; in Mykolaiv region there were 19454 crimes recorded and only 7197 (36\%) persons were served a notification of suspicion. By contrast, in the western regions of Ukraine, the crime rate is 2-3 times lower than in the southern regions. For instance, in the same year, in Transcarpathian region there were 11378 crimes recorded and $4718(41 \%)$ persons were served a notification of suspicion; in IvanoFrankivsk region there were 8512 crimes recorded and 2929 (34\%) persons were served a notification of suspicion. It is necessary to note that in some regions the crime rate increased against the background of a

${ }^{8}$ Статистичний щорічник України за 2013 рік / Держ. служба статистики України; за ред. Осауленка О. Г.. Київ: Держаналітінформ, 2014. 534 с.

9 Чекмарьова I. М. Запобігання злочинності у прикордонних регіонах Півдня України : дис. ... канд. юрид. наук: 12.00.08. Одеса, 2017. 307 с. 
decreased number of suspects. Not to mention that there is a drop in the level of crimes disclosure in all regions of the country. For the past three years, the level of crime disclosure has dropped from $71 \%$ to $33.2 \%$, and in some regions from $86 \%$ to $30 \%$. Six or seven years ago, out of ten crimes committed, every seventh or eighth person was prosecuted. In recent years, out of ten crimes recorded, only 3 or sometimes 5 persons are prosecuted. It is necessary to note that during 2008-2010 the percentage of crime disclosure in the country varied from 70 to 78 percent. According to the statistics of the Ministry of Internal Affairs of Ukraine, the picture was as follows: in 2008, in Odessa region, out of 19777 crimes recorded, $77.2 \%$ (16321 crimes) were disclosed; in Mykolaiv region out of 11008 crimes recorded, 81.5\% (9615) of persons were revealed; in Kherson region, out of the 9838 crimes recorded, $76.5 \%$ (833 people) were disclosed. These levels remained unchanged back to $2012^{10,11,12}$, after which the level of disclosure and the number of suspicions rapidly dropped.

The rate of criminal activity of certain population groups is an important indicator of the crime rate of the regions. If talking about this indicator, in recent years the highest crime rate with a coefficient of 934 per 100 thousand people aged 14 to 70 years is observed the territory of Kherson region. Mykolaiv region took second place with 739 per 100 thousand people aged 14 to 70 . Odessa region has the lowest crime rate with an indicator of 460 criminals per 100 thousand people aged 14 to 70 . Since Ukraine-wide indicators are 488 per 100 thousand people aged 14 to 70 , the criminal activity of the population of Odessa region is almost equal to the national level of crime rate, while the crime rate of Kherson and Mykolaiv regions two times higher than the Ukraine-wide indicators. Based on the results of the criminological study and statistical data, we have found out that the overwhelming majority of crimes are committed by men $-87.1 \%$ and

10 Стан та структура злочинності в Україні (2009-2010 pp.). URL: http://mvs.gov.ua/mvs/control/main /uk/publish/article/374130 (дата звер- нення: 10.02.2018).

11 Стан та структура злочинності в Україні (2010-2011 pp.). URL: http://mvs.gov.ua/mvs/control/main/ uk/publish/article/717134 (дата звер- нення: 10.02.2018).

Стан та структура злочинності в Україні (2007-2008 pp.). URL: http://mvs.gov.ua/mvs/control/main/uk/publish/article/170319 (дата звернен ня: 10.02.2018). 
$12.9 \%$ of crimes are committed by women. ${ }^{13,14}$ This data are peculiar to the border Black Sea regions of Ukraine, as confirmed by the results of polling of law enforcement officers and relevant statistical data.

The distribution of criminal activity among different age groups is another distinguishing feature of a regional offender. According to the criminological studies $^{15,16}$, the most numerous group consists of persons aged 18 to 28 years. Their share is on average about $35 \%$ of the total number of detected persons suspected of committing crimes. The offenders aged 29-39 years, which is about 33\% of all detected criminals, hold the second place in terms of numerical strength. The percentage of persons aged $40-59$ years was $24 \%{ }^{17}$. The share of juvenile offenders in Ukraine is about $5 \%$, while these indicators were distributed by regions as follows: Odesa region $-5.62 \%$; Mykolaiv region $-4.5 \%$ and Kherson region - 2\%. A group of 60-year old and above is inconsiderable in number - about 2.8-3 percent. In general, according to criminal statistics, in Ukraine and studied regions, the highest criminal activity is attributed to the categories of persons aged from 18 to 40 years. Based on our estimations, the aggregate share in the overall structure of criminals is about $70 \%$, namely, persons aged 18 to 28 years commit $33 \%$ of crimes, 29 to 40 years $-36 \%$.

The boundary regions of the Black Sea region of Ukraine are characterized by negative dynamics of increasing criminal activity among population and pronounced regional peculiarities. While from 2008 to 2016, a decrease was observed in officially registered criminal activity in Ukraine by $-9 \%$, this rate in Odessa region was $-18 \%$. On the contrary, Kherson and Mykolaiv regions show a tendency towards increase in the criminal activity among population. Mykolaiv region shows an increase of $+8 \%$, and Kherson $-+32 \%$. In our opinion, the above data is mainly due to the results of the law enforcement agencies work. They do not fully reflect the real state of affairs, because they do

13 Кулик О. Г. Кримінологічна характеристика осіб, які вчинили злочини в Україні: сучасні тенденції. Юрид. Україна. Сер.: Кримінально-правові науки. 2013. № 7. С. $98-102$.

${ }^{14,16}$ Фролова О. Г. Злочинність і система кримінальних покарань (соціальні, правові та кримінологічні проблеми й шляхи їх вирішення за допомогою логіко-математичних методів) : навч. посіб. Київ: АртЕк, 1997. 208 с.

${ }^{15,17}$ Кулик О. Г., Наумова I. В., Бова А. А. Злочинність в Україні: фактори, тенденції, протидія (2002-2014pр.) : монографія. Київ: ДНДІ МВС України, 2015. 364 c. 
not take into account the high level of latency of crime and those who actually commit a crime.

Based on the analysis of the individual peculiarities of the criminals in Odesa, Mykolaiv and Kherson regions, such social group as "persons with no steady source of income" is of a special criminological interest. Representatives of this group commit crimes most often; as a rule, a high rate of relapse is recorded among them. This social group is quite numerous. Most of them are people with a very low standard of living and a distorted attitude towards traditional human values. The numerical strength of this group of population is quite significant. According to regional criminological studies ${ }^{18}$, it is an average of 90 percent. For example, based on our estimations of official statistics with regard to the occupation of persons who committed crimes in 2016, the most criminogenic groups included the categories of "able-bodied persons, who neither work nor study" (79.8\%) and "unemployed" $(14.2 \%)$. The aggregate proportion of these categories in the overall structure of individuals in terms of occupation was $94 \%$. Such group of persons as "students of the educational institutions", for various reasons, amounted to $5.64 \%$, while the category of "civil servants" amounted to $0.18 \%$, "local government officials" - $0.1 \%$, and "elected officials" - only $0.04 \%$. The specified indicators not only show the impoverishment and "marginalization" of entire population strata of the Ukrainian regions and, as a result, their criminalization, but also work priorities of the law enforcement agencies. Against the backdrop of high levels of corruption and shadow economy of Ukraine, the regional law-enforcement agencies detect no more than $1 \%$ of individuals potentially involved in this phenomenon.

Consequently, a cumulative analysis of crime determinants and study of criminals' identity provides grounds to assert that there is a substantial basis for further complicating of the criminal situation in the boundary regions of the Black Sea group. Due to the socio-demographic factors, the growth of crime in the studied regions is highly probable for account of the unemployed, refugees, internally displaced persons, and others alike. These can also include the foreigners from far and near abroad. Based on own research results, as well as statistical data

${ }^{18}$ Веприцький Р. С. Феноменологія злочинності в регіоні : монографія. Харків: Золота миля, 2014. 324 с. 
analysis $^{19,20,21,22,23}$ of the Prosecutor's Office of Odesa, Mykolaiv and Kherson regions, it should be noted that the social exclusion of the individuals, who do not have a permanent source of income, every year, makes them committing most mercenary and selfish- violent crimes more than 60\%; crimes against human life and health - from 7 to $10 \%$; crimes in the field of distribution of narcotic drugs, psychotropic substances, their analogues or precursors - from 5 to $7 \%$. According to R. S. Veprytskyi, the above category of persons commit the highest number of crimes: persons, who neither work nor study $-67.5 \%$; unemployed $-9.7 \%$; freelancers $-8.0 \%$; students $-2.6 \%$; entrepreneurs (without formation of a legal entity) - 2.3\%; other persons $-8.3 \%$. Hence, it turns out that the proportion of criminals among those who do not have a permanent source of income is 10-15 times higher than those who work. The described data, based on the results of studying trial sentences, are confirmed by the example of Odesa, Mykolaiv and Kherson regions. Consequently, the social danger of the described category of persons is extremely high. They have the highest probability of committing crimes. This is primarily due to the lack in provisioning of basic needs for food, clothing, housing, and alike. The described results determine the priorities in the general social prevention of crime.

Local mass media and law enforcement agencies are expressing a legitimate concern about the criminal expansion across the territories of Odesa, Mykolaiv and Kherson regions. Due to specifics of geographic, climatic and socio-economic conditions of Odesa, Mykolaiv and Kherson regions, they attract domestic and foreign criminals-migrants. In recent years, the issue became topical of crimes committed by the foreigners from far and near abroad. The transitional points are

${ }^{19}$ Сдиний звіт про кримінальні правопорушення за січень-грудень 2016 року / Прокуратура Миколаївської області. 2017. URL: http://myk.gp.gov.ua/

${ }^{20}$ Єдиний звіт про кримінальні правопорушення за січень-грудень 2015 року / Прокуратура Миколаївської області. 2016. URL: http://myk.gp.gov.ua/

${ }^{21}$ Сдиний звіт про кримінальні правопорушення за січень-грудень 2016 року/ Прокуратура Херсонської області. 2017. URL: http://www.kherson.gp.gov.ua/ ua/documents.html?dir_id=113257\&libid=100142 (дата звернення: 10.02.2018).

${ }_{22}$ Сдиний звіт про кримінальні правопорушення за січень-грудень 2015 року / Прокуратура Одеської області. 2016. URL: http://od.gp.gov.ua/ua/

${ }^{33}$ Єдиний звіт про кримінальні правопорушення за січень-грудень 2016 року / Генеральна прокуратура України. 2017. URL: http://www.gp.gov.ua/ ua/stst2011.html?dir_id=112661\&libid=100820 (дата звернення: 10.02.2018). 
organized in the boundary settlements; illegal migration is becoming widespread. Economic interests constitute the main reason for population migration to the studied regions: access to cheap raw materials; unrestricted access to sales of consumer goods (mainly from Turkey and China); unregulated land market due to privatization and bankruptcy of many enterprises of resort and production significance; the territories of the boundary regions of the Black Sea group turned out to be attractive for criminals involved in laundering of proceeds from crime.

As is well known, moral settings and the psychological atmosphere of the immediate social environment of a person is crucial for the development and consolidation of asocial, unlawful skills and behaviour stereotypes. $^{24}$ In this regard, during 2014-2015, an expert group of specialists from the Odesa State University of Internal Affairs conducted a comprehensive monitoring of the youth environment in the Odesa region. According to the results of an anonymous questionnaire, the expert group received data showing that only $52 \%$ of young people have a solid set about socially beneficial behaviour. While $46 \%$ of the respondents identified psychological readiness for committing crimes, $36 \%$ of respondents assumed the possibility of committing minor offenses; $6 \%$ - non-serious criminal offenses; $4 \%$ - serious criminal offenses. About $20 \%$ of respondents expressed readiness to commit grave and especially grave crimes against a person for material reward: to beat a person $-9 \%$; deprive a stranger of life $-5 \%$; deprive a friend or close person of life $-3 \%$. Almost $20 \%$ of the respondents approved the anti-social behaviour of other persons. ${ }^{25}$

The leading idea of the consciousness of the young population in the studied region is the desire for enrichment. Thus, the specialists of the Odesa State University of Internal Affairs ${ }^{26}$ recorded a high level of corruption in the consciousness of students (60\% of respondents). Most of the respondents were participants or witnesses of various kinds of

24 Абросімова Ю. А. Злочинність неповнолітніх та запобігання їй на регіональному рівні : дис. ... канд. юрид. наук: 12.00.08. Львів, 2009. 261 с.

${ }_{25,26}$ Користін О. С., Бабенко А. М. Моніторинг девіантної поведінки студентської молоді Одеського регіону та напрями іï профілактики у ВНЗ. Кримінально-правові та кримінологічні заходи протидї злочинності : зб. матеріалів Всеукр. наук-практ. конф., м. Одеса, 13 листопада 2015 р. Одеса: ОДУВС, 2015. C. 81-83. 
corruption, and a large number of them showed tolerance, and sometimes, sympathy for those who commit corrupt acts or receive large amounts of material wealth illegally. ${ }^{27}$ The fact was potentially dangerous that a large number of juveniles and youth in the Odesa region sympathize with the presence and activities of extremist youth organizations that promote the cult of violence and cruelty. Almost one in five, or $18 \%$ of the respondents, directly stated that they are attracted to being a member of such an organization (12\%), previously attracted $(3 \%)$, will be attracted in the future $(3 \%)^{28}$. The given results indicate the presence of negative processes in the formation of a specific psychological environment in the studied region. Such a situation adversely affects the regional criminal situation and constitutes grounds for exacerbating crime, including youth, in the event of symbiosis of criminogenic social, economic and political catalysts.

\section{Criminal and Legal Characteristics of Personality of a Criminal}

As part of our study, special attention is paid to the criminal-legal characteristics of the personality of criminals, namely: sustainability of unlawful behaviour, individual or group nature of the crime, etc. Data regarding the sustainability and intensity of illegal activity of individuals, individual or group nature of criminal behaviour, psychophysiological condition provide a more complete idea of the territorial specificity of illegal activity, define the categories of persons who need increased preventive attention.

The social group of "persons who had committed crimes" is a dangerous social group in the criminological structure of the population of the Southern boundary regions. These are the individuals, who have already been subject to measures of legal influence for the commission of crimes. They constitute a significant proportion of those who commit crimes. Based on this the crime situation in the studied regions is defined as quite tense. The increase in the number of relapses indicates the

${ }^{27}$ Користін О. С., Бабенко А. М. Моніторинг девіантної поведінки студентської молоді Одеського регіону та напрями її профілактики у ВНЗ. Кримінально-правові та кримінологічні заходи протидї злочинності : зб. матеріалів Всеукр. наук.практ. конф., м. Одеса, 13 листопада 2015 р. Одеса: ОДУВС, 2015. C. $81-83$.

${ }^{28}$ Ibidem. 
sustainability of crime in the regions and ineffectiveness of work of the regional law enforcement agencies in preventing recidivism. Reduced number of "recidivists" in statistical reports means improving their professionalism, high latency of crime and increased degree of organization. Consequently, we considered the data concerning persons who previously committed criminal offenses, as a very important carrier of criminological information. According to experts, the very existence of preliminary conviction or the experience of another illegal activity is a real indicator of the duration of criminal activity and resilience of antisocial orientation of individuals. In terms of regions, such information serves to prioritize the planning and organization of crime prevention activities. ${ }^{29}$

In this regard, in terms of the regional structure of a significant share of persons, who were notified of suspicion, and who had previously committed criminal offenses, we recorded: in Kherson region - 3708 (or 46\%); second place according to the criminal activity of those who had previously committed criminal offense - Mykolaiv region - 2900 (40\%). In Odesa region, the factor of preliminary criminal activity was recorded at the level of 1877 (20.37\%) persons. Thus, based on the duration of criminal activity and resilience of anti-social orientation of individuals, Kherson and Mykolaiv regions are twice more dangerous than Odesa region, which has the same number of penitentiary institutions in the form of imprisonment as the neighbouring territories: Odesa region -6 , in Mykolaiv -7 and Kherson $-6 .{ }^{30}$ Such a distribution shows not so much the increased determination of regional recidivism by social and economic factors, but the shortcomings in the regional organization for combating recidivism.

Based on findings of the criminologists, drug and alcohol abuse adversely effects the psychological and social spheres of life and activity of a person. Narcotic or alcohol dependence is a stimulant not only for negative behaviour in general, but also for the commission of various crimes. Based on results of studying statistical data and sentences in criminal proceedings, we found that a sign of intoxication has a pronounced regional specificity among persons committing crimes.

${ }^{29}$ Бабенко А. М. Запобігання злочинності в регіонах України: концептуально методологічний та праксеологічний вимір : монографія. Одеса: ОДУВС, 2014. 416 с.

${ }^{30}$ Ibidem. 
Thus, as of 2016, in Odesa region more than 7\% (656) of persons committed crimes in a state of alcohol or drug intoxication; Mykolaiv and Kherson regions - 9.55 (688) and 9.1 (731) percent, respectively. The crimes committed in a state of intoxication are characterized by absurdity, excessive and unjustified cruelty, and are often committed using firearms or knives. The vivid examples of such a situation are cases brought to the court and confirmed by the relevant court sentences. For example, the verdict of the Beryslav District Court of Kherson region dated 16.06.2015, case No. 658/278/15-К, criminal proceedings No. 1-кп/647/59/2015, determined guilty the citizen P. - temporary unemployed, previously unconvicted, with no criminal record, pursuant to article 89 of the Criminal Code of Ukraine, in committing crimes under Part 1 Article 263, Part 2 Article 15, Clause 1, Part 2 Article 115, Part 1 Article 115 of the Criminal Code of Ukraine, with a final sentence of imprisonment for twelve years. On September 24, 2014, at about 11:40 am, the specified citizen, being in a state of intoxication, near the entrance No. 2 of the building number 116 at Karl Libknekht street in the city of Kakhovka, Kherson region, pursuing a direct intent, aimed at unlawful deprivation of life of two persons M. and V., in the course of a conflict that arose suddenly on the ground of personal hostile relations, using a firearm - revolver, made one shot into the vital human organ head of M., which caused the latter severe bodily injuries, dangerous to life, and resulted in his death. Continuing the implementation of criminal intent aimed at murder of two persons the citizen P. made one shot from the specified revolver within area of the body of V., which caused the latter light bodily injuries, resulted in a short-term health disorder. ${ }^{31}$

A vivid example of neglecting human life and using of insignificant reason for murder is the verdict of the Prymorsk District Court of Odesa dated April 17, 2015, case No. 522/20315/14-к, proceedings No. 1-кп/ 522/1044/14, which convicted temporarily unemployed citizen Z. under Part 1 Article 115 of the Criminal Code of Ukraine to 9 (nine) years in prison for the crime committed on August 02, 2014, at about 1:00 am, when the specified citizen, being in a state of intoxication, moving down Didrikhson street towards Staroportofrankivska street in Odesa, passing near the building number 7 at Didrikhson street, which was poorly

${ }^{31}$ Сдин. держ. реєстр суд. рішень України. URL: http://www.reyestr.court.gov.ua/ Page/7 (дата звернення: 10.02.2018). 
lighted, collided his left shoulder with citizen $\mathrm{K}$, who was moving towards him. In connection with this, a verbal quarrel arose, which converted into a brawl, as a result of which citizen $\mathrm{K}$. tried to strike with his right hand the citizen $\mathrm{Z}$ in the area of the head, but the latter, having the skills in hand-to-hand combat, intercepted the hand and began to hold, while taking out of the pocket of jeans with his right hand the balisong "knife-butterfly", using which, by striking a neck, committed a deliberate murder of the citizen $\mathrm{K}^{32}$

Another example is set forth in the verdict of the Kotovsk City Court of Odesa region dated April 16, 2015, case No. 503/527/15-К, proceedings No. 1-кП-505/195/15, which determined guilty the unemployed citizen $\mathrm{O}$. in the commission of a criminal offense provided for in Part 1 Article 115 of the Criminal Code of Ukraine and punished him in the form of 8 (eight) years of imprisonment. On January 14, 2015 , at about 11:30 pm, the said person, being in a state of intoxication, while in the premises of the summer kitchen, on the grounds of suddenly arising personal hostile relations that arose as a result of a verbal conflict, anticipating and wishing for death of the victim, inflicted about three strokes with axe head on the head, causing severe bodily injuries, from which the latter died on the spot. ${ }^{33}$ Thus, the analysis results of statistics and convictions in criminal proceedings indicate that individuals intoxicated, for insignificant reasons and with undue cruelty; as well as using the cold and firearms are committing the majority of crimes. Specialists also argue that in fact, the widespread crime of this category is complicity prevalent.

With regard to the latter characteristic, the criminology proved that group members under the influence of the group have a setting and value orientations formed, which include the setting and methods of addressing vital problems. The group's impact on the individual is very significant: its members communicate on a daily basis, relations between them are based mainly on feelings, and their relationship to each other and assessment of various social facts, events and other people inevitably manifested in an emotional form. The mood and views that prevail in the group are passed on to its associates. Therefore, the

${ }^{32}$ Єдин. держ. реєстр суд. рішень України. URL: http://www.reyestr.court.gov.ua/ Page/7 (дата звернення: 10.02.2018).

${ }^{33}$ Ibidem. 
intensity and duration of the negative impact on the individual from the party of the microenvironment, which covers not only the mind and will of the individual, but also his feelings and emotions, are understandable. Regarding this characteristic, in terms of regions, the greatest number of crimes committed by a group of people is committed in Mykolaiv $696(9.7 \%)$, in the second place Odesa region $-673(7.3 \%)$ and Kherson region $-458(5.7 \%)$.

Numerous examples of forensic investigations indicate the high social danger and increase of crimes committed by a group of people in the studied regions. Thus, the verdict of the Komsomolskyi District Court in Kherson dated 20.08.2015, criminal proceedings No. 667/4011/15-K, determined guilty the unemployed citizens L. and S. in the commission of a crime, stipulated in clause 12 Part 2 Article 115 of the Criminal Code of Ukraine, and sentenced each of them to 11 years' imprisonment. The indicated citizens, on April 05, 2015, at about 11:00 am, while in the apartment of citizen O., acting on the basis of a preliminary conspiracy, during a sudden conflict for domestic reason related to the personal hostile relations, deliberately, having a direct intent of causing death to another person, stricken with the kitchen knives numerous chaotic blows to vital organs in the regions of body, chest, abdomen, neck of the victim, from which the latter died. ${ }^{34}$

According to research results, we did not find a significant statistical dependence on the impact of national attributes in persons who committed crimes on the territory of the studied regions. Ukrainians committed the vast majority of crimes in Odesa, Mykolaiv and Kherson regions - from $97.7 \%$ to $99.57 \%$ of crimes, while foreigners committed from 0.43 crimes in Kherson, and $2.3 \%$ in Odesa region.

For the proper organization of crime prevention, objective distribution of forces and means of preventing crime, information about the most common places in which persons commit crimes is of a great importance. Objective information on this subject was grouped in the data below based on the analysis of statistics on crime and individuals committed crime in the three regions of the Ukrainian Black Sea region. According to the data received, analysis results of the criminal and legal statistics and expert surveys of specialists who are directly involved in

${ }^{34}$ Єдин. держ. реєстр суд. рішень України. URL: http://www.reyestr.court.gov.ua/ Page/7 (дата звернення: 10.02.2018). 
crime prevention in the boarding areas of the Black Sea region of Ukraine, it is established that the overwhelming majority of people commit crimes in the cities and settlements of urban type. In Odesa region, such crimes are committed by $70.5 \%$ of the identified individuals among those who have been notified of suspicion. Kherson and Mykolaiv regions, these indicators were at almost 68\%. At the same time, such regional centres as Odessa and Mykolaiv are more attractive in terms of committing crimes. Almost $40 \%$ of detainees committed crimes here, while in the countryside, the criminals committed about $30 \%$ of offenses. In Kherson region, in terms of the crime site, the accused from villages and regional centres were distributed equally $30 \%$ each group. At the same time, public places turned out to be the most attractive in terms of committing crimes in Odesa and Mykolaiv regions, where offenders commit crimes at a level 14-19\%. Kherson region - only $7.2 \%$ of criminals commit crimes in public places.

The experience of practical activities supported by interviewing law enforcement officers and research results of criminal proceedings ${ }^{35}$ provide grounds for arguing that in the Black Sea border, depending on the crimes committed, there are certain social and criminological features of the identity of the perpetrators. On the example of the bordering regions, we have established consistent patterns of criminals on a social map of society with various strata. The regional crimes of different types have inherent own social portrait, as evidenced by the criminology and its methodology.

Thus, according to our data, which correlate with the criminological research, we have obtained results that represent the middle class and higher social strata among killers and rapists in a smaller number than the "lower" segments of the population. The vast majority of crimes in the southern regions of the border area are committed in the so-called "underworld". ${ }^{36}$ Violent crime, as a rule, associates with the alcohol and drug abuse, low culture, everyday conflicts, preliminary conviction, lack of permanent sources of earnings.

With regard to mercenary or economic crime, the analysis of criminal proceedings indicates a completely different social composition

${ }^{35}$ Єдин. держ. реєстр суд. рішень України. URL: http://www.reyestr.court.gov.ua/ Page/7 (дата звернення: 10.02.2018).

${ }^{36}$ Ibidem. 
of criminals. This factor is most clearly manifested through the prism of the subject of the crime and extent of the harm caused. For example, we recorded the representatives of the "social underworld", as a rule, during the commission of crimes provided for in parts 1, 2 or 3 of Articles 185190 of the Criminal Code of Ukraine with an insignificant extent of harm caused, while theft, smuggling in large and especially large amounts, vehicle theft - are most common among more "privileged" parts of society.

The pronounced differences in the socio-economic characteristics of criminals are also observed when comparing the qualified and most severe types of official crimes. We associate these regional peculiarities of the distribution among criminals with the peculiarities of the life of separate groups formed in accordance with the social product distribution rules between various strata in the bordering areas of the Black Sea region of Ukraine, availability of certain benefits, existence of social ties, barriers to obtaining material goods and differences in the level of living between different regions of the border group.

\section{CONCLUSIONS}

To summarize, it can be noted that the analysis of the main characteristics of the criminal identity gives grounds to assert that in the boundary region of the South of Ukraine the absolute majority of crimes are committed by unemployed young men aged 18-40 years, most of whom being unmarried at the time of committing crime, but were formerly married. Most of individuals, who committed crime, had secondary education, were unemployed and studied nowhere at the time of committing crime; they are characterized by low culture and intellectual development. Almost half of the perpetrators were previously convicted of a crime (in half of the criminal cases related to violence), which is characterized by an early recurrence. The above characteristics should be taken into account in crime prevention process at the regional level, as well as during detection and investigation of criminal proceedings, programs development and planning crime prevention measures in the boundary regions of the South of Ukraine.

\section{SUMMARY}

This paper deals with the criminological characteristics of persons who committed crimes in the boundary regions of the South of Ukraine. 
It was established that Odesa, Mykolaiv, and Kherson regions became attractive centres of criminality concentration. The border-zone factor for criminals facilitates illegal activity, increases the attractiveness of criminal activity in terms of planning and committing crimes, disappearing from the crime site and avoidance of criminal responsibility. It is established that in the absolute majority - more than $66 \%$ of crimes are being committed by young males aged 18-40 years. The vast majority of those who committed crimes had a secondary education, neither worked nor studied at the time of committing crime. Almost half of the perpetrators were convicted earlier, and they are characterized by an early recidivism. The attention is focused on the fact that a large number of persons who committed crimes were in a state of intoxication. The absurdity, excessive and unjustified cruelty, often with the use of firearms or cold weapons, are often characteristic of the activities of criminals in the studied regions.

\section{REFERENCES}

1. Шакун В. I. Урбанізація і злочинність : монографія. Київ: УABC, 1996. $256 \mathrm{c}$.

2. Ковалкин А. А. Личность преступника и некоторые способы её криминологического анализа. Проблемы изучения личности правонарушителя: сб. научн. тр. Москва: Изд-во ВНИИ МВД CCCP, 1984. $158 \mathrm{c}$.

3. Кулик О. Г. Кримінологічна характеристика осіб, які вчинили злочини в Україні: сучасні тенденції. Юрид. Україна. Сер.: Кримінально-правові науки. 2013. № 7. С. 98-102.

4. Чекмарьова I. М. Особливості кримінологічних ознак особи злочинця для запобігання злочинності. Development of Legal Regulation in East Europe: Experience of Poland and Ukraine (Sandomierz, Poland, 27-28.01.2017). Sandomierz, Poland, 2017. C. $178-181$.

5. Кримінологія: Загальна частина : альбом схем / авт. упоряд.: Денисов С. Ф., Денисова Т. А., Кулик С. Г., Шеремет О. С. Чернігів: Десна, 2015. 658 с.

6. Джужа О. М., Кондратьєв Я. Ю., Кулик О. Г. Кримінологія : підручник та ін. Київ: Юрінком Інтер, 2002. 416 с. 
7. Кулик О. Г., Наумова І. В., Бова А. А. Злочинність в Україні: фактори, тенденції, протидія (2002-2014pр.) : монографія. Київ: ДНДІ МВС України, 2015. 364 с.

8. Статистичний щорічник України за 2013 рік / Держ. служба статистики України; за ред. Осауленка О. Г. Київ: Держаналітінформ, 2014. $534 \mathrm{c.}$

9. Чекмарьова I. М. Запобігання злочинності у прикордонних регіонах Півдня України : дис. ... канд. юрид. наук: 12.00.08. ОДУВС. Одеса, 2017. 307 с.

10. Стан та структура злочинності в Україні (2009-2010рр.). URL: http://mvs.gov.ua/mvs/control/main /uk/publish/article/374130 (дата звернення: 10.02.2018).

11. Стан та структура злочинності в Україні (2010-2011рр.). URL: http://mvs.gov.ua/mvs/control/main/ uk/publish/article/717134 (дата звернення: 10.02.2018).

12. Стан та структура злочинності в Україні (2007-2008рp.). URL: $\quad$ http://mvs.gov.ua/mvs/control/main/uk/publish/article/170319 (дата звернення: 10.02.2018).

13. Кулик О. Г. Кримінологічна характеристика осіб, які вчинили злочини в Україні: сучасні тенденції. Юрид. Україна. Сер.: Кримінально-правові науки. 2013. № 7. С. 98-102.

14. Фролова О. Г. Злочинність і система кримінальних покарань (соціальні, правові та кримінологічні проблеми й шляхи їх вирішення за допомогою логіко-математичних методів) : навч. посіб. Київ: АртЕк, 1997. 208 с.

15. Веприцький Р. С. Феноменологія злочинності в регіоні : монографія. Харків: Золота миля, 2014. 324 с.

16. Сдиний звіт про кримінальні правопорушення за січень-грудень 2016 року / Прокуратура Миколаївської області. 2017. URL: http://myk.gp.gov.ua/

17. Сдиний звіт про кримінальні правопорушення за січень-грудень 2015 року / Прокуратура Миколаївської області. 2016. URL: http://myk.gp.gov.ua/

18. Єдиний звіт про кримінальні правопорушення за січень-грудень 2016 року / Прокуратура Херсонської області. 2017. URL: $\quad$ http://www.kherson.gp.gov.ua/ua/documents.html?dir_id= 113257\&libid=100142 (дата звернення: 10.02.2018). 
19. Сдиний звіт про кримінальні правопорушення за січень-грудень 2015 року / Прокуратура Одеської області. 2016. URL: http://od.gp.gov.ua/ua/

20. Єдиний звіт про кримінальні правопорушення за січень-грудень 2016 року / Генеральна прокуратура України. 2017. URL: http://www.gp.gov.ua/ua/stst2011.html?dir_id=112661\&libid= 100820 (дата звернення: 10.02.2018).

21. Прикордонники у минулому році припинили діяльність понад 150 протиправних групп. URL: http:/dpsu.gov.ua/ua/news/ Prikordonniki-pripinili-u-minulomu-roci-diyalnist-ponad-150-protipr avnih-grup (дата звернення: 10.02.2018).

22. Абросімова Ю. А. Злочинність неповнолітніх та запобігання їй на регіональному рівні : дис. ... канд. юрид. наук: 12.00.08. Дніпроп. ун-т внутр. справ. Львів, 2009. 261 с.

23. Користін О. Є., Бабенко А. М. Моніторинг девіантної поведінки студентської молоді Одеського регіону та напрями іiі профілактики у ВНЗ. Кримінально-правові та кримінологічні заходи протидї злочинності : зб. матеріалів Всеукр. наук-практ. конф., м. Одеса, 13 листопада 2015 р. Одеса: ОДУВС, 2015. С. 81-83.

24. Бабенко А. М. Запобігання злочинності в регіонах України: концептуально-методологічний та праксеологічний вимір : монографія. Одеса: ОДУВС, 2014. 416 с.

25. Сдин. держ. реєстр суд. рішень України. URL: http://www.reyestr.court.gov.ua/ Page/7 (дата звернення: 10.02.2018).

\section{Information about author:} Konopelskyi V. Ya.

Doctor of Juridical Sciences, Associate Professor, Professor at the Departament of Criminal Law and Criminology, Odesa State University of Internal Affairs 1, Uspenska str., Odesa, 65014, Ukraine 